\title{
Effect of Sugar Mill Effluents on Ground Water Quality
}

\author{
Sunil Kumar ${ }^{1}$, Manish Kumar ${ }^{2 *}$, Anuradha Kumari ${ }^{2}$, Amit Kumar ${ }^{3}$ and A.K. Singh ${ }^{1}$ \\ ${ }^{1}$ Dr. R.P.C.A.U., Pusa, Samastipur-848125, Bihar, India \\ ${ }^{2}$ G.B. Pant University of Agricultural and Technology, Pantnagar, Uttrakhand-263153, India \\ ${ }^{3}$ M.P.U.A.T, Udaipur, Rajasthan-313001, India \\ *Corresponding author
}

\section{A B S T R A C T}

\begin{tabular}{|l|}
\hline Ke y w o r d s \\
Sugar mill, \\
Effluents, Ground \\
water, Quality \\
parameter, \\
Pollution.
\end{tabular}

\section{Introduction}

Groundwater has emerged as the dominant place in agriculture and food security in India. It is estimated that over $60 \%$ of irrigated agriculture, which itself is $70 \%$ of the total in India, is covered by groundwater (http://www.iimahd.ernet.in/publications/data/ 2009-03-08Gandhi.pdf). However, 71\% of our earth is covered with water, but salt free water is only $3 \%$ of the total. In fact, very small part of the salt free water $(0.007 \%$ of the total) is having such a quality to satisfy human needs (http://environment.national geographic.co.in/environment/freshwater/fresh water-crisis/).
Of the world, India is having $2.6 \%$ of land and $17 \%$ of the population with only $4 \%$ of the water resources Draft National Water Policy (2012) as recommended by National Water Board in its 14th Meeting held on 7th June, 2012.

The main factors responsible for increasing water pollution are exponential growth of population, urbanization, industrialization and agricultural revolution. Groundwater quality is affected due to discharge of poor quality water from various industries and urban waste water to the natural water courses. The sugar 
industry contain remnants of chemical used for processing like caustic soda, sodium chloride, lime, sulphur and softening agents etc. which degrade the quality of groundwater.

During the last few decades, disposal of sewage-sludge without proper treatment from urban areas and effluents from industries have caused the deterioration in the quality of groundwater. The need has arisen to review and recognise environmental problems associated with sugar mills. The effluents discharged from the sugar factories, distilleries etc. introduced in to the groundwater might be causing undesirable qualities. Therefore, the present study has been carried out to assess the various quality parameters of ground water sample of different water bodies situated in the vicinity of sugar mills.

\section{Materials and Methods}

The research activities were carried out at the College of Agricultural Engineering, Rajendra Agricultural University, Pusa. Altogether 30 groundwater samples of various sources were collected from surrounding areas of the sugar mills located at Gopalganj and Hassanpur (Table 1) according as water quality standard guideline APHA, WHO. All the samples (1 litre each) were treated with 2-3 drops of toluene before analysing in the laboratory to assess the various quality parameters to check the microbial growth.

\section{Methodology}

\section{Measurement of pH}

The $\mathrm{pH}$ was determined by immersing the electrodes of $\mathrm{pH}$ meter in a $100 \mathrm{ml}$ clean beaker containing about $50 \mathrm{ml}$ of the water sample. The $\mathrm{pH}$ meter measured the electromotive force across the electrodes in water samples. The meter was graduated to read directly in $\mathrm{pH}$ units along with the electromotive force $(\mathrm{mV})$ scale. A standard buffer solution (of known $\mathrm{pH}$ ) was used to calibrate the instrument before determining the $\mathrm{pH}$ of test solutions.

\section{Measurement of Electrical Conductivity (EC)}

The electrical conductivity was measured by dipping the cell of the EC meter in $40 \mathrm{ml}$ water sample and expressed as $\mu \mathrm{mhos} / \mathrm{cm}$ at $25^{\circ} \mathrm{C}$.

\section{Sodium}

The determinations of $\mathrm{Na}$ and $\mathrm{K}$ were carried out directly with the help of flame photometer using appropriate filters and standard curves prepared.

The curve was drawn by plotting flame photometer readings at $589 \mathrm{~nm}$ (when excited in a gas flame) against the known concentrations $(5,10,20,40$ and $50 \mathrm{me} / \mathrm{l})$. The concentrations of $\mathrm{Na}$ in the unknown samples were read from the curve.

\section{Calcium and magnesium (EDTA titration method)}

$5 \mathrm{ml}$ of the water sample in a porcelain dish was diluted to about $25 \mathrm{ml}$ distilled water. One $\mathrm{ml}$ of ammonium chloride-ammonium hydroxide buffer and 3 to 4 drops of Erichrome Black $\mathrm{T}$ indicator were added and titrated with the standard Versanate solution. The colour change was wine red to blue or bluish green. From the volume of $0.01 \mathrm{~N}$ EDTA (standardized against $0.01 \mathrm{~N} \mathrm{CaCl}_{2}$ ) solution required for titration, the concentration of $\mathrm{Ca}^{2+}+\mathrm{Mg}^{2+}$ was obtained directly in me/l as below:

$\mathrm{Ca}^{2+}+\mathrm{Mg}^{2+} * 1000$ 
$\mathrm{V}_{\mathrm{v}}=\mathrm{ml}$ of Versanate solution used, $\mathrm{N}=$ Normality of Versanate solution and

$\mathrm{Vs}=$ Volume of aliquot taken $(\mathrm{ml})$

Carbonates and bicarbonates (Richards, 1954)

The estimation was based on simple acidimetric titration using different indicators working in alkaline $\mathrm{pH}$ range (above 8.2 ) or in acidic $\mathrm{pH}$ (below 6.0). The reagents used were:

Phenolphthalein indicator: $0.25 \%$ solution in $60 \%$ ethyl alcohol

Methyl orange indicator: $0.5 \%$ solution in 95\% alcohol

Standard sulphuric acid $(0.01 \mathrm{~N})$

$5 \mathrm{ml}$ of the water sample was titrated against $0.01 \mathrm{~N}$ sulphuric acid until the disappearance of pink colour (Phenolphthalein end point) while conversion of Carbonate in to Bicarbonate and burette reading was noted as ' $Y$ ' ml. Further, it was titrated using methyl orange indicator (yellow) and the burette reading was noted as ' $\mathrm{Z}$ ' $\mathrm{ml}$. Consequently, the reaction was followed as:

(i) $\mathrm{CO}_{3}{ }^{2-}+\mathrm{H}_{2} \mathrm{SO}_{4}$ (' $\mathrm{Y}^{-} \mathrm{ml}$ ) $\mathrm{HCO}_{3}{ }^{-}$(ii) $\mathrm{CO}_{3}{ }^{2-}+$ $\mathrm{H}_{2} \mathrm{SO} 4$ ('Z $\mathrm{Z}^{\prime}$ ) $\mathrm{H}_{2} \mathrm{CO}_{3}^{-}$

Carbonate and bicarbonate were calculated as

$\mathrm{CO}_{3}{ }^{2-}=2 \mathrm{Y}^{*} \mathrm{~N} *(1000 / \mathrm{Vs})=2 \mathrm{Y}^{*} 2=4 \mathrm{Y} \quad \&$ $\mathrm{HCO}_{3}{ }^{-}=(\mathrm{Z}-2 \mathrm{Y}) * 2 * \mathrm{~N} *(1000 / \mathrm{Vs})=(\mathrm{Z}-2 \mathrm{Y}) * 2$

\section{Residual Sodium Carbonate (RSC)}

It was calculated from the analysis data for carbonates plus bicarbonates (me/l) and Calcium plus Magnesium (me/l) in the following manner:
$\mathrm{RSC}=\left(\mathrm{CO}_{3}{ }^{2-}+\mathrm{HCO}_{3}{ }^{-}\right)-\left(\mathrm{Ca}^{2+}+\mathrm{Mg}^{2+}\right)$

\section{Sodium adsorption ratio}

Sodium adsorption ratio was synthesized from known concentration of $\mathrm{Na}^{+}$and $\mathrm{Ca}^{2+}+\mathrm{Mg}^{2+}$ as follows:

$\mathrm{SAR}=\mathrm{Na} /(\mathrm{Ca}+\mathrm{Mg})$

\section{Total dissolved solid}

The total dissolved solid was calculated by multiplying the EC value $(\mathrm{dS} / \mathrm{m})$ by a factor 640 and expressed in ppm or $\mathrm{mg} / \mathrm{l}$.

$\operatorname{TDS}(\mathrm{ppm})=\mathrm{EC} * 640$

\section{Chloride}

The Chloride concentration was determined by titration with silver nitrate $(0.02 \mathrm{~N})$. The silver nitrate solution was slowly added till the end point of titration occurred when all the Chloride ions were precipitated as silver chloride.

Then additional silver ions reacted with the chromate ions of the indicator (potassium chromate) to form a red-brown precipitate of silver chromate. The reactions were followed as:

(i) $\mathrm{Ag}^{+}$(aqueous) $+\mathrm{Cl}^{-}$(aqueous) $\rightarrow \mathrm{AgCl}$ (s) (ii) $2 \mathrm{Ag}^{+}$(aqueous) $+\mathrm{CrO}_{4}{ }^{2-}$ (aqueous) $\rightarrow$ $\mathrm{Ag}_{2} \mathrm{CrO}_{4}$ (s)

Firstly, $5 \mathrm{ml}$ of the sample (Vs) was brought to $\mathrm{pH} 7-8$ by adding $\mathrm{HNO} 3 / \mathrm{NaOH}$ after diluting it to about $25 \mathrm{ml}$ with water. It was then titrated with ' $\mathrm{X}$ ' $\mathrm{ml}$ standard $\mathrm{AgNO}_{3}$ solution (with stirring) by using 5 to 6 drops of $\mathrm{K}_{2} \mathrm{CrO}_{4}$ indicator until the first reddish brown precipitate appeared and $\mathrm{Cl}^{-}$was calculated as

$\mathrm{Cl}^{-}=(\mathrm{X} * \mathrm{~N}) *(1000 / \mathrm{Vs})=\mathrm{X}^{*}()=\mathrm{X} * 4$ 


\section{Nitrate-nitrogen}

Nitrates are the most oxidised forms of nitrogen and the end product of the aerobic decomposition of organic nitrogenous matter. The evaluation of nitrogen is of paramount importance in understanding the nutritional status of water bodies. Nitrate reacts with phenol di-sulphonic acid (PDA) to produce a nitro derivative, which in alkaline solution develops a yellow colour. The colour produced follows Beer's law and is proportional to the concentration of $\mathrm{NO}_{3}{ }^{-} \mathrm{N}$ present in the sample. The concentration of $\mathrm{NO}_{3}{ }^{-} \mathrm{N}$ was determined using a colorimeter or spectrophotometer.

A calibration curve was prepared by using suitable aliquots of 2, 5, 10, 15, 20 and $25 \mathrm{ml}$ standard nitrate $\left(\mathrm{KNO}_{3}\right)$ solution. Each of the aliquots were treated with $2 \mathrm{ml}$ of Phenol disulphonic acid before $10 \mathrm{ml}$ of concentrated $\mathrm{NH}_{3}$ (to develop colour) and then diluted to $100 \mathrm{ml}$ standard volumetric flasks. Contents were mixed well and the solutions from each of the standard flasks were transferred to a cuvette. The absorbance was measured at 410 $\mathrm{nm}$ wavelength filter using colorimeter. Simultaneously, a blank solution was prepared. A calibration curve was drawn by plotting absorbance against the concentration of $\mathrm{NO}_{3}{ }^{-} \mathrm{N}$. Using the calibration curve, the concentration of $\mathrm{NO}_{3}{ }^{-} \mathrm{N}$ in the water sample is determined. Concentration $(\mathrm{ppm})=4.8^{*}$ Dilution factor* O.D. reading of the sample (4.8 for standard solution)

\section{Water class rating (Wilcox Diagram)}

The rating of the water as regards its suitability for irrigation was done by referring to the standard chart available in the soil testing laboratory. The experimentally determined value of $\mathrm{Ca}^{2+}+\mathrm{Mg}^{2+}$ (in me/l) was spotted in the chart and perpendicular was drawn from that point. The EC value of the water (in the chart) was to be seen and from that point, a slanting line was drawn exactly in a similar manner in which the line from a next higher value was drawn. The point where the EC line intersected the perpendicular drawn from the $\mathrm{Ca}^{2+}+\mathrm{Mg}^{2+}$ spot would lie in a certain zone which gave the water class. A perpendicular from this point of intersection was extended to the SAR line meeting it at some point.

\section{Results and Discussion}

This study was taken up with a view to assess the quality of groundwater of different sources in the surrounding areas of Sasamusa sugar mill, Gopalganj (Table 2) and Hassanpur sugar mill, Samastipur (Table 3).

A $\mathrm{pH}$ range of 6.5-8.5 is normally acceptable as per guidelines suggested by WHO and BIS. The $\mathrm{pH}$ values near Sasamusa sugar mill was in the range of 8.2 to 8.6 , while that in the vicinity of Hassanpur sugar mill it varied from 6.8 to 8.0. The Electrical Conductivity near Sasamusa sugar mill varied from 330 to $910 \mu \mathrm{mhos} / \mathrm{cm}$ (at $25^{\circ} \mathrm{C}$ ), which was from 410 to $780 \mu \mathrm{mhos} / \mathrm{cm}$ (at $25^{\circ} \mathrm{C}$ ) near Hassanpur sugar mill and were found within the safe limit. Also, the concentration of total dissolved solids (TDS) was varying from 211 to $584 \mathrm{ppm}$ for Sasamusa mill and from 262 to $499 \mathrm{ppm}$ for Hassanpur mill. It followed as: excellent, <300 mg/l; good, between 300 and $600 \mathrm{mg} / \mathrm{l}$. Hence, perasal of data indicate that TDS was found within safe limit and could be used safely for drinking as well as irrigation purpose as proposed by (http://www.who. int/water_sanitation_health/dwq/chemicals/td s.pdf).

The concentration of $\mathrm{CO}_{3}{ }^{2-}+\mathrm{HCO}_{3}$ (alkalinity) was varying from $95-520 \mathrm{ppm}$ (in terms of $\mathrm{CaCO}_{3}$ ). Thus, it was also creating obstruction in using water for drinking purpose. 
The concentration of $\mathrm{Ca}^{2+}+\mathrm{Mg}^{2+}$ ranged from 400 to $1200 \mathrm{mg} / \mathrm{l}$ near the mill of Sasamusa, while it was 550 to $1350 \mathrm{mg} / \mathrm{l}$ around Hassanpur sugar mill. The concentration of $\mathrm{Ca}+\mathrm{Mg}$ was found much higher nearby sugar mills and declined almost upto 8-10 Kmaway from the both sugar mills in a definite trend However, high concentration (> 600 ppm) might be developing scales on the water heater, boiler and cooking utensils and also increased soap consumption for washing and was unsuitable for drinking and domestic purpose. It was classified as soft $(<75 \mathrm{mg} / \mathrm{l})$, hard $(75-300 \mathrm{mg} / \mathrm{l})$ and very hard (> 300 $\mathrm{mg} / \mathrm{l})$ in terms of $\mathrm{CaCO}_{3}$ (www.dpi.nsw.gov.au, Agfact AC.2, 9th edition, April 2005). The high concentration of $\mathrm{Ca}^{2+}+\mathrm{Mg}^{2+}$ disclosed hardness of water and indicated that such water was not suitable for irrigation purpose. Excessive hardness might also be causing foliar deposits of Calcium or Magnesium Carbonate under overhead irrigation.

$\mathrm{NO}^{-}$- $\mathrm{N}$ content in water samples varied from 6.8 to $7.7 \mathrm{ppm}$ and from 6.9 to $7.5 \mathrm{ppm}$ at both sugar mill and was found within safe limit for drinking and irrigation purpose.

Table.1 Sampling of Groundwater of various sources

\begin{tabular}{|c|c|c|c|c|}
\hline $\begin{array}{c}\text { S. } \\
\text { No. }\end{array}$ & Source & Depth (ft) & Distance (km) & \multirow{3}{*}{ Sugar mill } \\
\hline 1 & D.T.W. & 200 & 0.0 & \multirow{3}{*}{} \\
\hline 2 & H.P. & 50 & 0.1 & \\
\hline 3 & H.P. & 50 & 1.0 \\
\hline 4 & H.P. & 45 & 2.0 \\
\hline 5 & H.P. & 55 & 3.0 \\
\hline 6 & H.P. & 45 & 4.0 \\
\hline 7 & H.P. & 55 & 5.0 \\
\hline 8 & H.P. & 50 & 6.0 \\
\hline 9 & D.T.W. & 250 & 7.5 \\
\hline 10 & H.P. & 45 & 8.5 \\
\hline 11 & H.P. & 40 & 10.0 \\
\hline 12 & H.P. & 50 & 11.0 \\
\hline 13 & D.T.W. & 250 & 13.0 \\
\hline 14 & H.P. & 55 & 13.5 \\
\hline & & & \\
\hline 15 & D.T.W. & 400 & 0.0 \\
\hline 16 & H.P. & 40 & 0.0 \\
\hline 17 & H.P. & 45 & 1.0 \\
\hline 18 & H.P. & 45 & 1.0 \\
\hline 19 & H.P. & 70 & 2.0 \\
\hline 20 & H.P. & 50 & 2.5 \\
\hline 21 & H.P. & 45 & 3.0 \\
\hline 22 & H.P. & 50 & 4.0 \\
\hline 23 & H.P. & 55 & 4.5 \\
\hline 24 & H.P. & 70 & 5.0 \\
\hline 25 & H.P. & 100 & 7.5 \\
\hline 26 & H.P. & 50 & 9.0 \\
\hline 27 & H.P. & 45 & 10.0 \\
\hline 28 & H.P. & 40 & 11.0 \\
\hline 29 & H.P. & 55 & 13.0 \\
\hline 30 & H.P. & 55 & \\
\end{tabular}


Table.2 Characteristics of pre-monsoon groundwater samples around Sasamusa sugar mill, Gopalganj

\begin{tabular}{|c|c|c|c|c|c|c|c|c|c|c|c|c|}
\hline $\begin{array}{l}\text { S. } \\
\text { No. }\end{array}$ & Distance & pH & EC & $\mathrm{Na}$ & $\mathrm{Ca}^{2+}+\mathrm{Mg}^{2+}$ & $\begin{array}{c}\mathrm{CO}_{3}^{2-} \\
+ \\
\mathrm{HCO}^{3-} \\
\end{array}$ & RSC & SAR & TDS & $\mathrm{Cl}^{-}$ & $\begin{array}{c}\mathrm{NO}_{3}^{-} \\
\mathbf{N}\end{array}$ & $\begin{array}{l}\text { Irrigation } \\
\text { class }\end{array}$ \\
\hline & Km & & umhos/cm & $\mathrm{mg} / \mathrm{l}$ & $\begin{array}{c}\text { mg } \\
\mathrm{CaCO}_{3} / \mathrm{l} \\
\end{array}$ & $\begin{array}{c}\mathrm{mg} \\
\mathrm{CaCO}_{3} / \mathrm{l} \\
\end{array}$ & $\mathrm{me} / \mathrm{l}$ & & ppm & $\mathrm{mg} / \mathrm{l}$ & Ppm & \\
\hline 1 & 00.0 & 8.4 & 390 & 3.67 & 1200 & 170 & \multirow{14}{*}{$\begin{array}{l}(-) \\
\text { ve }\end{array}$} & 1.06 & 250 & 8.80 & 6.8 & $\mathrm{C}_{2} \mathrm{~S}_{1}$ \\
\hline 2 & 00.1 & 8.3 & 410 & 3.73 & 1160 & 150 & & 1.10 & 262 & 10.4 & 6.9 & $\mathrm{C}_{2} \mathrm{~S}_{1}$ \\
\hline 3 & 01.0 & 8.5 & 820 & 6.22 & 1000 & 180 & & 1.97 & 525 & 9.60 & 6.9 & $\mathrm{C}_{3} \mathrm{~S}_{1}$ \\
\hline 4 & 02.0 & 8.5 & 370 & 0.73 & 0770 & 120 & & 0.26 & 237 & 8.00 & 6.9 & $\mathrm{C}_{2} \mathrm{~S}_{1}$ \\
\hline 5 & 03.0 & 8.4 & 400 & 2.53 & 0760 & 135 & & 0.33 & 256 & 9.20 & 7.3 & $\mathrm{C}_{2} \mathrm{~S}_{1}$ \\
\hline 6 & 04.0 & 8.4 & 560 & 1.82 & 0700 & 120 & & 0.69 & 358 & 8.40 & 7.0 & $\mathrm{C}_{2} \mathrm{~S}_{1}$ \\
\hline 7 & 05.0 & 8.6 & 490 & 2.01 & 0680 & 135 & & 0.77 & 314 & 8.80 & 6.9 & $\mathrm{C}_{2} \mathrm{~S}_{1}$ \\
\hline 8 & 06.0 & 8.4 & 360 & 1.24 & 0525 & 110 & & 0.54 & 230 & 8.80 & 7.0 & $\mathrm{C}_{2} \mathrm{~S}_{1}$ \\
\hline 9 & 07.5 & 8.5 & 330 & 0.64 & 0490 & 110 & & 0.29 & 211 & 11.2 & 6.8 & $\mathrm{C}_{2} \mathrm{~S}_{1}$ \\
\hline 10 & 08.5 & 8.2 & 910 & 6.14 & 0475 & 095 & & 2.82 & 582 & 11.6 & 7.7 & $\mathrm{C}_{3} \mathrm{~S}_{1}$ \\
\hline 11 & 10.0 & 8.3 & 850 & 6.88 & 0490 & 110 & & 3.11 & 544 & 11.6 & 8.9 & $\mathrm{C}_{3} \mathrm{~S}_{1}$ \\
\hline 12 & 11.0 & 8.6 & 430 & 6.67 & 0450 & 130 & & 3.14 & 275 & 11.8 & 6.9 & $\mathrm{C}_{2} \mathrm{~S}_{1}$ \\
\hline 13 & 13.0 & 8.6 & 880 & 7.30 & 0460 & 180 & & 3.40 & 563 & 11.8 & 6.9 & $\mathrm{C}_{2} \mathrm{~S}_{1}$ \\
\hline 14 & 13.5 & 8.5 & 410 & 9.46 & 0400 & 160 & & 4.73 & 262 & 13.2 & 7.1 & $\mathrm{C}_{2} \mathrm{~S}_{1}$ \\
\hline
\end{tabular}

Table.3 Characteristics of pre-monsoon groundwater samples around Hassanpur sugar mill, Samastipur

\begin{tabular}{|c|c|c|c|c|c|c|c|c|c|c|c|c|}
\hline \multirow{2}{*}{$\begin{array}{l}\text { S. } \\
\text { No. }\end{array}$} & Distance & pH & EC & $\mathbf{N a}$ & $\begin{array}{l}\mathrm{Ca}^{2+}+ \\
\mathrm{Mg}^{2+} \\
\end{array}$ & $\begin{array}{l}\mathrm{CO}_{3}{ }^{2+}+ \\
\mathrm{HCO}^{3-} \\
\end{array}$ & RSC & SAR & TDS & $\mathrm{Cl}^{-}$ & $\mathrm{NO}_{3}{ }^{-} \mathrm{N}$ & \multirow{2}{*}{$\begin{array}{l}\text { Irrigation } \\
\text { class }\end{array}$} \\
\hline & km & & $\boldsymbol{\mu m h o s} / \mathrm{cm}$ & $\mathrm{mg} / \mathrm{l}$ & $\mathrm{mg} / \mathrm{l}$ & $\mathrm{mg} / \mathrm{l}$ & $\mathrm{mg} / \mathrm{l}$ & & ppm & $\mathrm{mg} / \mathrm{l}$ & ppm & \\
\hline 1 & 00.0 & 8.0 & 780 & 9.13 & 1325 & 260 & \multirow{16}{*}{$(-) v e$} & 2.48 & 499 & 12.0 & 6.9 & $\mathrm{C}_{3} \mathrm{~S}_{1}$ \\
\hline 2 & 00.0 & 7.3 & 750 & 8.86 & 1350 & 520 & & 2.41 & 461 & 12.6 & 7.4 & $\mathrm{C}_{3} \mathrm{~S}_{1}$ \\
\hline 3 & 01.0 & 7.7 & 750 & 8.12 & 1210 & 235 & & 2.19 & 474 & 12.0 & 7.4 & $\mathrm{C}_{2} \mathrm{~S}_{1}$ \\
\hline 4 & 01.0 & 7.4 & 750 & 6.88 & 1200 & 235 & & 2.29 & 474 & 10.8 & 6.9 & $\mathrm{C}_{2} \mathrm{~S}_{1}$ \\
\hline 5 & 02.0 & 7.7 & 480 & 8.26 & 0900 & 130 & & 2.15 & 307 & 09.2 & 6.9 & $\mathrm{C}_{3} \mathrm{~S}_{1}$ \\
\hline 6 & 02.5 & 6.8 & 650 & 7.86 & 0800 & 260 & & 1.71 & 416 & 08.4 & 6.9 & $\mathrm{C}_{3} \mathrm{~S}_{1}$ \\
\hline 7 & 03.0 & 7.3 & 540 & 7.24 & 0650 & 175 & & 2.84 & 346 & 07.9 & 7.0 & $\mathrm{C}_{3} \mathrm{~S}_{1}$ \\
\hline 8 & 04.0 & 7.7 & 530 & 4.89 & 0630 & 170 & & 1.95 & 339 & 07.6 & 6.9 & $\mathrm{C}_{3} \mathrm{~S}_{1}$ \\
\hline 9 & 04.5 & 7.9 & 560 & 4.36 & 0620 & 230 & & 1.52 & 358 & 07.2 & 7.5 & $\mathrm{C}_{3} \mathrm{~S}_{1}$ \\
\hline 10 & 05.0 & 7.0 & 750 & 6.04 & 0590 & 245 & & 2.03 & 474 & 08.8 & 7.0 & $\mathrm{C}_{3} \mathrm{~S}_{1}$ \\
\hline 11 & 07.5 & 7.8 & 410 & 2.70 & 0550 & 120 & & 1.15 & 262 & 06.6 & 6.9 & $\mathrm{C}_{3} \mathrm{~S}_{1}$ \\
\hline 12 & 09.0 & 7.4 & 420 & 5.25 & 0800 & 260 & & 2.39 & 269 & 06.6 & 7.3 & $\mathrm{C}_{3} \mathrm{~S}_{1}$ \\
\hline 13 & 10.0 & 7.6 & 520 & 4.14 & 0700 & 200 & & 1.28 & 333 & 06.6 & 7.1 & $\mathrm{C}_{3} \mathrm{~S}_{1}$ \\
\hline 14 & 11.0 & 8.0 & 640 & 5.61 & 0825 & 260 & & 1.95 & 410 & 06.8 & 7.0 & $\mathrm{C}_{3} \mathrm{~S}_{1}$ \\
\hline 15 & 12.0 & 7.5 & 590 & 6.03 & 0625 & 245 & & 2.41 & 378 & 07.2 & 7.2 & $\mathrm{C}_{3} \mathrm{~S}_{1}$ \\
\hline 16 & 13.0 & 7.4 & 420 & 6.57 & 1035 & 355 & & 3.21 & 269 & 08.4 & 7.0 & $\mathrm{C}_{3} \mathrm{~S}_{1}$ \\
\hline
\end{tabular}


Table.4 Classification for salinity

\begin{tabular}{|c|c|c|c|}
\hline Salinity Category & EC $\left(\boldsymbol{\mu m h o s} / \mathbf{c m}\right.$ at $\left.\mathbf{2 5}^{\mathbf{0}} \mathbf{C}\right)$ & No. of sources in category & Percentage of sources \\
\hline Low & $<250$ & 0 & 0 \\
\hline Medium & $250-750$ & 21 & 70.0 \\
\hline High & $750-2250$ & 9 & 30.0 \\
\hline Very High & $>2250$ & 0 & 0 \\
\hline
\end{tabular}

Table.5 Chloride classification of irrigation water

\begin{tabular}{|c|c|c|c|}
\hline Chloride (ppm) & Effect on crops & No. of samples & Percentage \\
\hline$<70$ & Generally safe for all plants & 0 & 00.00 \\
\hline $70-140$ & Sensitive plants show injury & 0 & 00.00 \\
\hline $140-350$ & Moderately tolerant plants show injury & 19 & 63.33 \\
\hline$>350$ & Can cause severe problems & 11 & 36.67 \\
\hline
\end{tabular}

The chloride content in water samples were in the range of 284 to $468.6 \mathrm{ppm}$ for Sasamusa mill, while nearby Hassanpur mill, it was varying from 234.3 to $447.3 \mathrm{ppm}$. It was certainly unsafe (> 250ppm) for drinking and irrigation which causing toxicity to sensitive crops purpose (Indian Standard Specifications for drinking water Is: 10500).

In present investigation all the water samples were categorized based on the salinity hazard (Table 4). It is well known that the most influential water quality parameter for crop productivity was measured by electrical conductivity $\left(\mathrm{EC}_{\mathrm{w}}\right)$. Its high value might be causing inability of the plant to compete with ions in the soil solution for water (physiological drought).

Thus, table 4 revealed that the EC values ranging from 330 to $910 \mu \mathrm{mhos} / \mathrm{cm}$ were either in medium $(70.0 \%)$ or high (30.0) saline category. Thus, salt tolerant crops (Alfalfa, Barley, Bermuda grass, Corn, Cotton, Sorghum, Soybean and Wheat etc.) could be suggested for saline areas (Rhoades et al., 1992 and Fipps, 2003) according as the other factors suitability.

SAR values indicated that ground water samples of various waterbodies were low in sodium content and were found within acceptable range for drinking and irrigation purpose (Garg et al., 2008).

It was evident from the data that chloride contents were unsafe for irrigation as discussed earlier. All samples were also classified for irrigation purposed by considering chloride content in present study (Table 5) as proposed by Bauder et al., 2012.

The categorization of irrigation classes was carried out following the water quality chart (Richards, 1954). Based on the categorization of irrigation classes, all the sources came under either medium $\left(\mathrm{C}_{2} \mathrm{~S}_{1}\right)$ or high salinity hazard $\left(\mathrm{C}_{3} \mathrm{~S}_{1}\right)$. Hence, special management for salinity control with salt tolerant crops were required.

Groundwater quality parameters viz. $\mathrm{Ca}^{2+}+\mathrm{Mg}^{2+}, \quad \mathrm{CO}_{3}{ }^{2-}+\mathrm{HCO}_{3}{ }^{-}$and $\mathrm{Cl}^{-}$with alarming $\mathrm{pH}$ were certainly problematic for drinking as well as irrigation purpose in the locality of sugar mills. But, TDS was thought to be problem in future. However, $\mathrm{NO}_{3}^{-} \mathrm{-N}$, SAR and RSC were certifying the water for drinking and irrigation purposes as well.

Also the sources came under either medium $\left(\mathrm{C}_{3} \mathrm{~S}_{1}\right)$ or high $\left(\mathrm{C}_{2} \mathrm{~S}_{1}\right)$ salinity hazards. Hence, salinity control with salt tolerant crops could be recommended for the sugar mill locality. 


\section{References}

Bauder, T.A., Waskom, R.M., Sutherland, P.L. and Davis, J. G. (5/11) (2012). Irrigation Water quality Criteria.htm accessed.

Draft National Water Policy (2012) as Recommended By National Water Board in its 14th Meeting Held on 7th June, 2012.

Fipps, G. (2003). Irrigation Water Quality Standards and Salinity Management. Fact Sheet B-1667. Texas Cooperative Extension. The Texas A\&M University System, College Station, TX.

Garg, J., Joshi, A. and Seth, G. (2008). Hydro-geochemistry and quality assessment of ground water of Jaipur city and its adjoining area (Rajasthan). Int. J. Chem. Sci.: 6(1) 422-436

Guidelines for Drinking Water Quality (1993) Volume-1, Recommendations, WHO Geneva 172-18 pp. 53-79.

http://environment.nationalgeographic.co.in/e nvironment/freshwater/freshwater-crisis accessed on November, $4^{\text {th }} 2012$.

http://extension.umass.edu/floriculture/fact- sheets/water-quality-ph-and-alkalinity accessed on November, $5^{\text {th }} 2012$.

http://www.capitalhealth.ca/nr/rdonlyres/e46h 42vuy3uqkmaapv6voufgmf2sccz $7 \mathrm{gwvv}$ hz7ge57vqmgmstxfz6dans32ukzj4ocv2j 62jsbuqeu3dwhsvwqzt2b/interpretation ofchemicalanalysisofdrinkingwater.pdf accessed on November, $5^{\text {th }} 2012$.

http://www.iimahd.ernet.in/publications/data/ 2009-03-08Gandhi.pdf accessed on November, $5^{\text {th }} 2012$.

http://www.ksre.ksu.edu/irrigate/OOW/P06/P orter06.pdf accessed on November, $4^{\text {th }}$ 2012.

http://www.who.int/water_sanitation_health/d wq/chemicals/tds.pdf. Background document for development of WHO Guidelines for Drinking-water Quality.

Indian standard specifications for drinking water, IS: 10500 (1992).

Richards, P. R. Ed. (1954). Diagnosis and improvement of saline-alkali soils. Agric. Handbook U.S. Department Agril.60.

www.dpi.nsw.gov.au, Agfact AC.2, 9th edition, April 2005.

\section{How to cite this article:}

Sunil Kumar, Manish Kumar, Anuradha Kumari, Amit Kumar and Singh, A.K. 2017. Effect of Sugar Mill Effluents on Ground Water Quality. Int.J.Curr.Microbiol.App.Sci. 6(12): 169-176. doi: https://doi.org/10.20546/ijcmas.2017.612.022 